\title{
ANALYSIS OF FINANCIAL DISTRESS IN TRANSPORTATION COMPANIES WITH THE ALTMAN Z-SCORE APPROACH
}

\author{
Agus Irawan, Adi Prasetyo, Dwi Irawan*
}

' RAAR $\left.\right|_{\text {Accounting Research }} ^{\text {Review of Aplied }}$

Affiliation:

Accounting Department, Universitas Muhammadiyah

Malang, Indonesia

*Correspondence: irawan@umm.ac.id

Article Process:

Submitted:

September 10, 2021

Reviewed:

September 19, 2021

Revised:

October, 1, 2021

Accepted:

October 9, 2021

Published:

October 10, 2021

\section{Citation:}

Irawan. A., Prasetyo, A., \& Irawan, D., (2021). Analysis Of Financial Distress In Transportation Companies With The Altman Z-Score

Approach. RAAR: Review of

Applied Accounting

Research, 1(2), 66-74.

\section{Office Address:}

Jl. K.H. Ahmad

Dahlan, Dukuhwaluh,

Kec. Kembaran, Kab.

Banyumas, Jawa

Tengah 53182

e-ISSN : 2807-8969

\begin{abstract}
This study aims to analyze the potential for bankruptcy or financial distress of companies in the public transportation sub-sector listed on the Indonesia Stock Exchange using the Altman Z-score model approach. The population of this study are transportation companies listed on the Indonesia Stock Exchange for the 2017-2019 period, the sample is only taken from the 3 largest transportation companies operating on land, sea and air. The results of calculations using the Altman Z-score method show that there is one company that is prone to bankruptcy. A business that is expected to go bankrupt in the year under review does not mean it will go bankrupt, it is just a warning to the business about the state of the business so that it can anticipate the most likely losses.
\end{abstract}

Keywords: Altman Z-score, Financial Distress, Transportation Company

\section{ABSTRAK}

Penelitian ini bertujuan untuk menganalisis potensi kebangkrutan atau financial distress pada perusahaan subsektor transportasi umum yang terdaftar di Bursa Efek Indonesia dengan menggunakan pendekatan model Altman Z-score. Populasi penelitian ini adalah perusahaan transportasi yang terdaftar di Bursa Efek Indonesia periode 2017-2019, sampel hanya diambil dari 3 perusahaan transportasi terbesar yang beroperasi di darat, laut dan udara. Hasil perhitungan dengan menggunakan metode Altman Z-score menunjukkan bahwa terdapat satu perusahaan yang rawan bangkrut. Suatu usaha yang diperkirakan akan bangkrut pada tahun yang ditinjau bukan berarti akan bangkrut, melainkan hanya peringatan kepada pelaku usaha tentang keadaan usaha tersebut agar dapat mengantisipasi kerugian yang paling mungkin terjadi.

Kata kunci: Altman Z-score, Financial Distress, Perusahaan Transportasi 


\section{INTRODUCTION}

67 Indonesia is a developing country that is going to become a developed country, one of the things that supports the economy in Indonesia is the transportation sector because transportation is one of the most important things for every person and company in carrying out various activities. The types of transportation that can be used also vary, ranging from land, air, and sea transportation. Transportation is very important to connect raw material source areas, production areas, marketing areas, and residential areas as consumers' residences so that Indonesia as a very large country requires very large infrastructure costs (Simanjuntak et al., 2017).

Currently, there are 46 companies in the transportation sector listed on the Indonesia Stock Exchange (IDX). Therefore, each company has a different strategy to increase revenue in each company, there are also problems that cause bankruptcy both internally and externally. Internal factors that are meant are strategies rather than the company itself, while external factors are factors caused by outside the company such as land acquisition, natural disasters.

The number of cases in Indonesia regarding the value of the company has emerged, one of which is a transportation service company with a red plate with the issuer code GIAA or PT. Garuda Indonesia. Tbk, which has been losing money for a long time because corporate governance has dropped in managing the risks it faces, causing the value of the company to decrease by 2.31 percent in 2017 before various cases emerged that befell the state-owned company.

To anticipate the occurrence of bankruptcy, the company should have early preparations to prevent unwanted things from happening. The company is expected to be able to assess the current condition of the company in order to obtain a clearer picture of the current condition of the company, so that the company's management can find out what actions are appropriate to maintain the company and correct deficiencies so that the company can survive and compete. Information like this can help companies make decisions and determine the right steps to make innovations or improvements that have an impact in the future (Kurniawati, 2016).

One of the tools used by companies to assess the condition or performance of the company is the financial statements that are produced each period. So that the company can know more clearly the condition of the period and can know more clearly the current condition of the company, the company can compare the current financial statements with the previous period's financial statements. Financial ratios can also be used to analyze the relationship of various items in financial statements as a basis for interpreting the good or bad condition of a financial (Jaya, 2014).

There are various analyzes developed to predict the beginning of the company's bankruptcy. One analysis that is widely used today is the Altman Z-Score analysis, where this analysis refers to the company's financial ratios. The ratio describes a relationship or balance between a certain amount with another amount. Meanwhile, what is used in the

RAAR Vol.1 No.2 analysis is the balance sheet and income statement (Safitra, 2013). Altman found five ratios that can be combined in a mathematical formula that is accurate in predicting corporate bankruptcy. 
The interesting thing about the Z-Score is that it is an analytical tool regardless of the size of the company. Even though the company is very prosperous, if the Z-Score shows a poor score, then the company should be careful. If a company goes bankrupt, many parties will be harmed. One of them is for investors and creditors who will be harmed. Investors will be disadvantaged because they have invested their shares in the company and creditors will lose because they have already provided loans which in the end cannot be repaid (uncollectible) (Rachmawati, 2016).

Prior research has sufficiently proven that the Altman Z-Score model is able to detect bankruptcy. Research conducted by Yati and Patunrui (2017) the results show that the Altman Z-Score model can be implemented in detecting the possibility of financial distress in pharmaceutical companies. One in ten companies have the lowest Z-Score and are experiencing financial stress. According to Iladina et al. (2018) this study aims to determine the prediction of bankruptcy outcomes and also to test whether there is an influence between the independent variables, namely the value of the financial ratio model of the Altman Z-score as a predictor of bankruptcy with the dependent variable being stock prices. The results showed that from 2014 to 2016 the majority of the textile and garment industry companies on the Indonesia Stock Exchange were in the category of companies that were gray area and went bankrupt.

The outbreak of COVID-19 has affected many industries. The industrial relations structure has certain important characteristics, with the risk of certain industries rapidly spreading to their upstream and downstream supply chains. At the same time, in order to prevent crossinfection caused by population flows during the epidemic period, many cities restrict traffic flow, directly affecting the transportation industry (Li et al., 2021). Indonesia is certainly one of those affected by the transportation industry. This is what underlies the importance of this research, namely to assess the potential for bankruptcy with the Altman Z-Score approach in transportation sector companies in Indonesia. Companies that are prone to bankruptcy are certainly not very profitable for potential investors.

\section{LITERATURE REVIEW}

Financial distress occurs before the company actually experiences bankruptcy. Platt and Platt (2002) define financial distress as the stage of decline in financial conditions that occurs before bankruptcy or liquidation. Meanwhile, Foster and Viswanathan (1990) defines a comparative analysis of predictions to mean severe liquidity problems that cannot be resolved without a sizable rescaling of the entity's operations or structure. Altman (1968) defines financial distress by using the numbers in the financial statements and representing it in a number, namely the Z-Score which can be a reference to determine whether a company has the potential to go bankrupt or not. Altman also classifies financial distress into four general terms, namely: 1) Economic Failure; 2) Business Failure; 3) Insolvency; 4) Legal Bankruptcy.

Bankruptcy of a company is characterized by a situation where the company is weak in generating profits or the company tends to run a deficit. In other words, bankruptcy can be interpreted as a company's failure to run the company's operations to earn a profit. Bankruptcy is also often called company liquidation or company closure or insolvency. Bankruptcy as a failure is defined as financial failure and economic failure (Adnan \& Kurniasih, 2000). Failure in an economic sense is a situation where the company loses 
money or the company's income cannot cover its own costs. This means that the present value of cash flows is actually less than liabilities or profit is less than working capital. Failure occurs when the actual cash flow of the company is far below the expected cash flow. In fact, failure can also mean that the level of income from historical costs or investments is less than the company's cost of capital (Safitra, 2013).

The bankruptcy prediction model is used to overcome and minimize the occurrence of bankruptcy, companies can monitor financial conditions by using financial statement analysis techniques. Financial statement analysis is an important tool to obtain information related to the company's financial position and the results that have been achieved in connection with the selection of the company's strategy that has been implemented. By analyzing the company's financial statements, it can be seen the condition and financial development of the company. Altman Z-score model as a measure of bankruptcy performance and Comparative Analysis Prediction of bond risk is not stagnant or fixed, but develops from time to time, along with the condition of the company and the conditions in which the method is applied (Dwijayanti, 2010).

The Altman Z-score approach uses Multiple Discriminant Analysis. Discriminant analysis is a statistical technique that identifies several types of financial ratios that are considered to have the most important value in influencing an event, then develop it in a model with the aim of making it easier to draw conclusions from an event. This discriminant analysis then produces a grouping that is a priori or based on theory from actual reality. Altman's rationale for using discriminant analysis stems from the limitations of ratio analysis, namely the methodology is basically a deviation, which means that each ratio is tested separately so that the effect of the combination of several ratios is only based on the considerations of financial analysts (Marsenne, 2020).

The use of the Altman model as a measure of bankruptcy performance is not permanent or stagnant but develops from time to time, where testing and model discovery continues to be expanded by Altman to its application not only to public manufacturing companies but also to non-public manufacturing companies, non-manufacturing companies, and corporate bond companies (Zulaikah \& Laila, 2016).

Over time and adjustments to various types of companies.modified his model so that it can be applied to all companies, such as manufacturing, non-manufacturing, and bond issuing companies in developing countries (emerging markets). In this modified Z-score, Altman eliminates the X5 variable (sales/total asset.) because this ratio varies widely in industries with different asset sizes.

\section{METHOD}

This type of research is a descriptive study that aims to predict the bankruptcy of companies in the transportation sub-sector for the period 2017-2019. The sample in this study used the quota sampling method, where researchers only took the 3 largest companies operating on land, sea and air (aviation). The type of data used in this study is secondary data in the form of annual financial statements of transportation sub-sector

RAAR Vol.1 No.2 companies for the 2017-2019 period. Data taken from the financial statements include current assets, current liabilities, total assets of retained earnings, profit before tax \& interest, total equity, and total liabilities. 
The data analysis method in the financial statements is used to measure, find out, predict, describe the possibility of bankruptcy in the transportation sub-sector companies listed on the Indonesian stock exchange. In analyzing the data that will be carried out in this study are:

1. Calculations on the ratio of working capital to total assets (X1)

2. Calculations on the ratio of retained earnings to total assets (X2)

3. Calculations on the ratio of profit before interest and taxes to total assets (X3)

4. Calculations on the ratio of book value of equity to book value of debt (X4)

5. Estimate bankruptcy for three big transportation companies listed on the Indonesian stock exchange which will be examined based on the Altman Z-score prediction model using the formula: $\mathrm{Z}$-score $=6,56 \mathrm{X} 1+3,26 \mathrm{X} 2+6,72 \mathrm{X} 3+1,05 \mathrm{X} 4$

6. Categorize each company according to the cut off that has been determined where:

a. Z-score $>2.60$ then the company is declared not bankrupt/healthy.

b. $1.1>$ Z-score $<2.60$ then the company is declared to be in the gray area or between bankrupt and not bankrupt

c. Z-score $<1.1$ then the company is declared bankrupt

\section{RESULT}

Based on the sample criteria in this study, so that the three largest transportation companies from land, sea, and air were selected. The three companies are PT. Blue Bird Tbk, Pt. Soechi Lines Tbk and PT. Garuda Indonesia Tbk.

Tabel 1. Financial Performance PT. Blue Bird Tbk.

\begin{tabular}{l|c|c|c}
\multirow{2}{*}{\multicolumn{1}{c|}{ Keterangan }} & \multicolumn{3}{|c}{ Tahun } \\
\cline { 2 - 4 } & 2017 & 2018 & 2019 \\
\hline Current Assets & 771.222 & 1.071 .773 & 938.785 \\
\hline Current Debt & 435.947 & 614.987 & 753.515 \\
\hline Total Assets & 6.516 .487 & 6.955 .157 & 7.424 .304 \\
\hline Retained Earnings & 2.062 .455 & 2.384 .410 & 2.496 .205 \\
\hline $\begin{array}{l}\text { Earning Before Interest and } \\
\text { Tax }\end{array}$ & 562.177 & 606.175 & 413.962 \\
\hline Book Value of Equity & 4.930 .925 & 5.265 .161 & 5.408 .102 \\
\hline Book Value of Debt & 1.585 .562 & 1.689 .996 & 2.016 .202 \\
\hline
\end{tabular}

$$
\mathrm{Z} \text {-SCORE }=6,56 \mathrm{X} 1+3,26 \mathrm{X} 2+6,72 \mathrm{X} 3+1,05 \mathrm{X} 4
$$

$$
\begin{aligned}
& 2017=6,56(0,051)+3,26(0,316)+6,72(0,086)+1,05(3,110)=5,214 \\
& 2018=6,56(0,066)+3,26(0,343)+6,72(0,087)+1,05(3,115)=5,405 \\
& 2019=6,56(0,025)+3,26(0,336)+6,72(0,056)+1,05(2,682)=4,451
\end{aligned}
$$

PT. Blue Bird Tbk based on the Altman Z-Score has excellent financial performance, this is evident from the Z-score value which is above 2.60, namely in 2017 it was 5,214, in 2018 it was 5,405, and in 2019 it was 4,451. It can be seen that the Z-score at PT. Blue Bird.Tbk for the last 3 (three) years has been in a healthy area so that it is categorized as a healthy company. 
Tabel 2. Financial Performance PT. Soechi Lines Tbk.

\begin{tabular}{l|r|r|r}
\hline \multirow{2}{*}{ Keterangan } & \multicolumn{3}{|c}{ Tahun } \\
\cline { 2 - 4 } & \multicolumn{1}{c|}{2017} & \multicolumn{1}{c}{2018} & \multicolumn{1}{c}{2019} \\
\hline Current Assets & 60.598 .354 & 93.316 .023 & 111.210 .547 \\
\hline Current Debt & 75.639 .439 & 36.719 .559 & 38.652 .304 \\
\hline Total Assets & 586.643 .112 & 669.877 .417 & 688.215 .790 \\
\hline Retained Earnings & 138.312 .226 & 150.703 .268 & 158.830 .655 \\
\hline $\begin{array}{l}\text { Earning Before Interest and } \\
\text { Tax }\end{array}$ & 23.266 .476 & 15.309 .792 & 13.037 .222 \\
\hline Book Value of Equity & 314.591 .153 & 327.213 .539 & 335.505 .606 \\
\hline Book Value of Debt & 272.051 .959 & 342.663 .878 & 352.710 .184 \\
\hline
\end{tabular}

$$
\mathrm{Z}-\mathrm{SCORE}=6,56 \mathrm{X} 1+3,26 \mathrm{X} 2+6,72 \mathrm{X} 3+1,05 \mathrm{X} 4
$$

$$
\begin{aligned}
& 2017=6,56(-0,026)+3,26(0,236)+6,72(0,040)+1,05(1,156)=2,081 \\
& 2018=6,56(0,084)+3,26(0,225)+6,72(0,023)+1,05(0,955)=2,444 \\
& 2019=6,56(0,105)+3,26(0,231)+6,72(0,019)+1,05(0,951)=2,570
\end{aligned}
$$

PT. Soechi Lines Tbk in the 2017-2019 period based on the Altman Z-Score had poor financial performance, it can be seen from the Z-Score value which is below 2.60. In 2017 it was 2,081 while in 2018 it was 2,444 and in 2019 it was 2,570. It can be seen that the ZScore value in the company PT. Soechi Lines. TBK in the last three years has been in a gray area so that it is categorized as a company that has financial difficulties, but the possibility of being saved and the possibility of going bankrupt is equally dependent on the decisions taken by the company's management.

Tabel 3. Financial Performance PT. Garuda Indonesia Tbk.

\begin{tabular}{l|r|r|r}
\hline \multirow{2}{*}{ Description } & \multicolumn{3}{|c}{ Period } \\
\cline { 2 - 4 } & \multicolumn{1}{c|}{2017} & \multicolumn{1}{c}{2018} & \multicolumn{1}{c}{2019} \\
\hline Current Assets & 986.741 .627 & 1.092 .915 .831 & 1.133 .892 .533 \\
\hline Current Debt & 1.921 .846 .147 & 2.976 .385 .526 & 3.257 .836 .267 \\
\hline Total Assets & 3.763 .292 .093 & 4.167 .616 .300 & 4.455 .675 .774 \\
\hline Retained Earnings & 6.081 .861 & 6.081 .861 & 6.081 .861 \\
\hline $\begin{array}{l}\text { Earning Before Interest and } \\
\text { Tax }\end{array}$ & -158.180 .637 & -221.052 .484 & 52.260 .433 \\
\hline Book Value of Equity & 937.469 .200 & 730.141 .803 & 720.622 .891 \\
\hline Book Value of Debt & 2.825 .822 .893 & 3.437 .474 .497 & 3.735 .052 .883 \\
\hline
\end{tabular}

$$
\mathrm{Z}-\mathrm{SCORE}=6,56 \mathrm{X} 1+3,26 \mathrm{X} 2+6,72 \mathrm{X} 3+1,05 \mathrm{X} 4
$$




$2017=6,56(-0,248)+3,26(0,002)+6,72(-0,042)+1,05(0,332)=-1,559$
$2018=6,56(-0,452)+3,26(0,001)+6,72(-0,053)+1,05(0,212)=-3,093$
$2019=6,56(-0,477)+3,26(0,001)+6,72(0,012)+1,05(0,193)=-2,841$

PT Garuda Indonesia Tbk in the 2017-2019 period based on the Altman Z-Score calculation is categorized as a company that is in an unhealthy condition. In 2017 it was 1,559 while in 2018 it was $-3,093$ and in 2019 it was -2, 841. It can be said that PT. Garuda Indonesia Tbk has poor financial performance, it is proven that the Z-Score value for 3 (three) consecutive years is below 2.60 which shows the company is in an unhealthy financial condition and has financial problems, so that financial difficulties and the possibility going bankrupt.

The Altman Z-score can be used as a tool to predict the level of potential for bankruptcy as well as an early warning for companies of signs of financial difficulties leading to bankruptcy, and can be used as a basis for decision making in determining more effective steps or strategies or efficient in maximizing the potential and existing company resources to generate a profit. Companies that are predicted to have the potential to go bankrupt in the year under study do not mean that the company is going bankrupt, this is only a warning to the company about the condition of the company so that the company can anticipate the worst possibility that will happen to the company in the future and make improvements to the company's performance and management, because the Altman Zscore method has the weakness of not having a definite time span when bankruptcy occurs after the analysis of the Z-score value is known to be lower than the standard that has been set. Therefore, there are several factors that must be considered in identifying the level of bankruptcy of a company, namely internal and external factors of the company such as economic conditions, political conditions, inflation rates, social, technological developments that have a major influence on the causes of bankruptcy.

\section{CONCLUSIONS AND SUGGESTIONS}

The results based on the Altman Z-score analysis show that transportation companies for the 2017-2019 period are experiencing financial difficulties because the Z-score results are below 2.60. Meanwhile, PT. Blue Bird. TBk with an average of 5,204 while the lowest is owned by PT. Garuda Indonesia. Tbk with an average of -2.498 . PT. Garuda Indonesia. Tbk has always been in the bankrupt category during the 2017-2019 period because it has a low Z-Score value, which is below 1.1. While PT. Blue Bird. Tbk in the 2017-2019 period is in the healthy/not bankrupt category because it has a value $>2.60$. PT. Soechi Lines. TBK is in the gray category for three consecutive periods because it has a calculation result of $1.1>\mathrm{Z}<2.60$.

In this position the company is on the verge of bankruptcy if policies are not immediately taken to improve the company's performance, but if the company is able to improve the company's performance it will be able to get out of the difficulties faced and avoid the possibility of bankruptcy. Altman Z-score is only an analytical tool, of course the actual condition really depends on the overall economic condition. The limitation of this study is that it only takes the three largest companies from the transportation sector, which conditions may have different results if carried out in other transportation companies. 
Further research can increase the number of observation samples or compare the method of bankruptcy analysis between Altman z-score with others or compare it with analysis of long-term company performance by including economic factors.

\section{REFERENCES}

Adnan, M. A., \& Kurniasih, E. (2000). Analisis Rasio CAMEL Terhadap Prediksi Kondisi Bermasalah Pada Lembaga Perbankan Periode 2000-2002. Jurnal Akuntansi dan Keuangan, 7(2).

Dwijayanti, S. P. F. (2010). Penyebab, dampak, dan pbediksi dari financial distress serta solusi untuk mengatasi financial distress. Jurnal Akuntansi Kontemporer, 2(2).

Foster, F. D., \& Viswanathan, S. (1990). A theory of the interday variations in volume, variance, and trading costs in securities markets. The Review of Financial Studies, 3(4), 593-624.

Iladina, F., Mardani, R. M., \& ABS, M. K. (2018). Analisis Metode Altman Z-Score Sebagai Alat Prediksi Kebangkrutan dan Pengaruhnya Terhadap HargaAdnan, M. A., \& Kurniasih, E. (2000). Analisis Rasio CAMEL Terhadap Prediksi Kondisi Bermasalah Pada Lembaga Perbankan Periode 2000-2002. Jurnal Akuntansi dan Keuangan, 7(2).

Dwijayanti, S. P. F. (2010). Penyebab, dampak, dan pbediksi dari financial distress serta solusi untuk mengatasi financial distress. Jurnal Akuntansi Kontemporer, 2(2).

Foster, F. D., \& Viswanathan, S. (1990). A theory of the interday variations in volume, variance, and trading costs in securities markets. The Review of Financial Studies, 3(4), 593-624.

Iladina, F., Mardani, R. M., \& ABS, M. K. (2018). Analisis Metode Altman Z-Score Sebagai Alat Prediksi Kebangkrutan dan Pengaruhnya Terhadap Harga Saham Pada Perusahaan Tekstil dan Garmen Yang Terdaftar di Bursa Efek Indonesia Tahun 2014-2016. Jurnal Ilmiah Riset Manajemen, 7(02).

Jaya, K. A. (2014). Laporan Keuangan Merupakan Alat Dalam Memprediksi Kecenderungan Terjadinya Kebangkrutan Perusahaan Dengan Menggunakan Model Altman (Studi Analisis). Jurnal Akuntansi, 18(2), 166-187.

Kurniawati, S. (2016). Analisis Kebangkrutan dengan Model Altman Z-Score Pada Perusahaan Subsektor Logam \& Sejenisnya di BEI Periode 2014. Paper presented at the Prosiding Seminar Nasional Cendekiawan.

Li, Z.-f., Zhou, Q., Chen, M., \& Liu, Q. (2021). The impact of COVID-19 on industryrelated characteristics and risk contagion. Finance research letters, 39, 101931.

Marsenne, M. (2020). Analisa Penggunaan Altman's Z-Score Untuk Memprediksi Kebangkrutan Perusahaan (Studi Kasus pada PT. Bank Permata, Tbk). Balance: Media Informasi Akuntansi dan Keuangan, 12(02), 56-74.

RAAR Platt, H. D., \& Platt, M. B. (2002). Predicting corporate financial distress: reflections on 
Rachmawati, T. (2016). Analisis Kebangkrutan Dengan Menggunakan Model Altman ZScore Pada Perusahaan Asuransi Yang Go Public Di Bursa Efek Indonesia (Periode Tahun 2010 - 2013). JEB17: Jurnal Ekonomi dan Bisnis, 1(01).

Safitra, B. A. (2013). Analisis Metode Altman (Z-score) Sebagai Alat Evaluasi Guna Memprediksi Kebangkrutan Perusahaan.(Studi Pada Industri Rokok Yang Terdaftar Di Bei Periode 2007-2011). Jurnal Administrasi Bisnis, 4(1).

Simanjuntak, C. E. B., Krist, F. T., \& Aminah, W. (2017). Pengaruh Rasio Keuangan Terhadap Financial Distress. eProceedings of Management, 4(2).

Yati, S., \& Patunrui, K. I. A. (2017). Analisis Penilaian Financial Distress Menggunakan Model Altman (Z-Score) Pada Perusahaan Farmasi Yang Terdaftar di Bursa Efek Indonesia Periode 2013-2015. Jurnal Akuntansi, Ekonomi dan Manajemen Bisnis, 5(1), 55-71.

Zulaikah, S., \& Laila, N. (2016). Perbandingan Financial Distress Bank Syariah Di Indonesia Dan Bank Islam Di Malaysia Sebelum Dan Sesudah Krisis Global 2008 Menggunakan Model Altman Zscore. Jurnal Ekonomi Syariah Teori dan Terapan, 3(11), 900-914. 